\title{
MIR337 Gene
}

National Cancer Institute

\section{Source}

National Cancer Institute. MIR337 Gene. NCI Thesaurus. Code C81801.

This gene is involved in the regulation of gene expression and plays a role in the development of epithelial ovarian carcinoma. 